\title{
Application of Saliva Inhibition to Detect Underlying Alloantibodies in Bombay Blood Group
}

\author{
Lingbo Wang $^{\mathrm{a}}$ Michael Crennan $^{\mathrm{a}}$ Angela Benic $^{\mathrm{a}}$ Derek Chiu $^{\mathrm{a}}$ Fiona Morris $^{\mathrm{b}}$ \\ Denise E. Jackson ${ }^{b}$ \\ aMelbourne Pathology, Melbourne, VIC, Australia; 'bSchool of Health and Biomedical Sciences, STEM College, \\ RMIT University, Melbourne, VIC, Australia
}

\section{Keywords}

Bombay · Anti-H · Saliva inhibition · Alloantibody $\cdot$ Thermal amplitude

\begin{abstract}
Introduction: The Bombay phenotype is a rare blood group determined by the absence of $\mathrm{H}$ antigens. Bombay individuals produce anti- $\mathrm{H}$, a clinically significant antibody that react against all $\mathrm{ABO}$ blood group. Anti-H can mask underlying alloantibody during antibody investigation, a challenge in current transfusion practice. The aim of this article is to explore saliva inhibition, a novel method to detect underlying alloantibody in Bombay individuals. Case Presentation: The case is a 93-year-old female transfused with pre-donated autologous blood for a surgery. We determined anti-H subclass and thermal amplitude, secretor status, and optimal ratio of saliva and Bombay plasma. Plasma samples containing anti$\mathrm{H}$ were spiked with anti-Fy(a) to determine the effectiveness of saliva inhibition in uncovering underlying alloantibodies. Results: Anti-H was confirmed to be predominately lgM with broad thermal amplitude. Tube immediate spin (IS) showed stronger anti-H reactivity compared to column agglutination technology (CAT). Spiked anti-Fy(a) was successfully detected using saliva inhibition method. Conclusion: Tube IS appears more sensitive to anti-H. Saliva inhibition appears to be a promising method to detect underlying alloantibody in the plasma of Bombay phenotype individuals.
\end{abstract}

(c) 2021 The Author(s).

Published by S. Karger AG, Basel

\section{Introduction}

Bombay phenotype was first reported by Dr Bhende in 1952 [1]. Bombay individuals lack $\mathrm{H}$ antigens on red cell membranes and in secretions. They also produce haemolytic anti-H antibodies reacting with red cells of all blood groups.

The fucosyl transferase FUT1 gene encodes L-fucose that defines the $\mathrm{H}$ antigen as a carbohydrate structure on the red cells. As $\mathrm{H}$ antigen is a precursor for addition of carbohydrates that define either A or B antigens, Bombay individuals lacking $\mathrm{H}$ antigen will phenotypically type as group $\mathrm{O}$.

The incidence of Bombay phenotype is $1 / 7,600$ in Mumbai, 1/10,000 in India, and 1/1,000,000 in Europe [2].

FUT1 and FUT2 secretor gene mutations are responsible for Bombay phenotype. A classic mutation described by Koda are missense mutation of FUT1:NM_00132987 7.1(FUT1):c.725T>G (p.Leu242Arg) and deletion of FUT2 [3].

Anti-H in Bombay individuals is a clinically significant antibody. It is naturally occurring, predominantly IgM, and reacting at broad thermal range [4]. It can bind complement and cause immediate acute haemolytic transfusion reaction as seen in a case report in Iran [5]. IgG anti$\mathrm{H}$ can cross placenta causing HDFN as demonstrated in a HDFN case [6]. As all non-Bombay individuals possess $\mathrm{H}$ antigens, Bombay individuals must be transfused with blood of Bombay phenotype only [7]. mercial purposes requires written permission.
Correspondence to:

Denise E. Jackson, denise.jackson@ rmit.edu.au 
In the laboratory, forward and reverse group of Bombay phenotype resembles $\mathrm{O}$ phenotype [8]. All screen cells and identification cells demonstrate positive reactions meaning underlying alloantibodies can be masked by the presence of anti-H.

A literature search revealed no investigations describing underlying alloantibodies in Bombay patients, probably due to low incidence of the phenotype and low risk of alloimmunization due to conservative treatments and autologous transfusion [9]. However, the risk is never zero. It is certainly possible for Bombay individuals to develop an alloantibody during pregnancy [10]. In a Bombay woman, routine antenatal antibody screening will be unable to determine whether the fetus is at risk of maternal alloimmunization to a red cell antigen.

The aim of this article was to study a rare Bombay case and to examine the application of saliva inhibition to investigate underlying alloantibody in Bombay individuals. Saliva of secretors contains soluble $\mathrm{H}$ antigens which can neutralize anti-H in Bombay plasma [11]. The study investigated: (1) anti-H Ig subclass and thermal amplitude, (2) secretor status confirmation to ensure $\mathrm{H}$ antigens are present in saliva, (3) optimization of saliva/Bombay plasma ratio to maximize reactivity while minimizing the dilutional effect, (4) spiking anti-Fy(a) in Bombay plasma where anti-Fy(a) was selected as it represents an IgG antibody of in vivo clinical significance in transfusion medicine, and (5) detection of spiked anti-Fy(a) in anti-H depleted Bombay plasma after saliva inhibition.

\section{Case Presentation}

A 93-year-old female presented to our hospital with a fractured humerus for a planned surgery. Pre-surgical haemoglobin was $86 \mathrm{~g} / \mathrm{L}$ with low iron stores. Group and screen and antibody investigation were performed on Bio-Rad IH-1000 using Immulab 0.8\% A1, B cells, Bio-Rad $0.8 \%$ screen cells, Immulab and Bio-Rad $0.8 \% 11$ cell panels. Forward and reverse group of patient appeared as $\mathrm{O} R \mathrm{Rh}(\mathrm{D})$ positive. Antibody screen and investigation showed panagglutination except auto control with reaction score 5-8 out of 12 . Patient was contacted for drug history in case of anti-CD38 treatment. We were informed by the patient she had anti-H. Red Cross Lifeblood was urgently contacted and Bombay phenotype was confirmed.

After discussion, patient was given EPO and iron infusion. HB was boosted to $99 \mathrm{~g} / \mathrm{L} 3$ days later. Further decision was made to use cryopreserved autologous $\mathrm{PRBC}$ units which were prepared more than 20 years ago. Three units were thawed and deglycerolized for $6 \mathrm{~h}$. All units were tested and found crossmatch compatible. The patient was transfused and post-operative $\mathrm{HB}$ was found to be above $100 \mathrm{~g} / \mathrm{L}$.

\section{Materials and Methods}

Reagent Preparation

All $0.8 \%$ reagent screen cells were prepared from $3 \%$ Immulab screen cells.

Alloantibodies Investigation Using Saliva

Inhibition in Bombay Blood Group

\section{Grading System}

All antibody reactions were scored using $0-12$ grading system.

\section{Ig Subclass and Thermal Amplitude Investigation}

Dithiothreitol (DTT) test described by Pirofsky et al. was used to identify whether anti-H was IgM or IgG [12]. DTT inhibits all IgM antibodies leaving IgG antibodies intact. If antibodies are detected on plasma with DTT treatment, it indicates IgG components. If antibodies are only detected on plasma without DTT treatment, it indicates IgM components. Three antibody detection techniques were compared in this study: Tube IS, CAT $(\mathrm{NaCl}$ card), and low ionic additive solution (LISS)/Coomb IAT. Saline control was also used to monitor dilution effects.

CAT ( $\mathrm{NaCl}$ card) method was used for thermal amplitude investigation. Four cards were set up and incubated under 4 different temperature conditions: 4 , RT, 30 , and $37^{\circ} \mathrm{C}$ for $15 \mathrm{~min}$.

\section{Secretor Status Confirmation}

Saliva from a B blood group secretor contains both free soluble $\mathrm{B}$ and $\mathrm{H}$ antigens while a non-secretor does not. Saliva from a known B Rh(D) positive volunteer was harvested and treated using Byrne method [13].

Four tubes were set up including testing and saline controls. Each tube had 3 components: $3 \%$ Immulab Revercell A1 or B, saliva or saline, and Immulab Anti-A or Anti-B.

Tube 1: A $1+$ saline + anti-A

Tube 2: $\mathrm{A} 1+$ saliva + anti-A

Tube 3: $\mathrm{B}+$ saline + anti-B

Tube 4: $\mathrm{B}+$ saliva + anti-B

One drop A1 or B cells was mixed with 5 drops saline or treated saliva. One drop of each mixture was then mixed with 2 drops Anti-A or Anti-B. Tube 1, 2, and 3 serve as positive controls. Tube 1 and 3 also serve as dilution controls. Negative reaction in Tube 4 means anti- $B$ is neutralized by soluble $B$ antigen which then indicates secretor. In contrast, positive reaction indicates non-secretor.

\section{Optimization of Saliva/Bombay Plasma Inhibition Reaction} Ratio

Five mixtures of treated saliva/Bombay plasma with different ratios $(2: 1,1: 1,0.5: 1,0.25: 1$, and $0.125: 1)$ were set up along with 5 saline controls. Each mixture was incubated at RT for $10 \mathrm{~min}$ before being tested against $0.8 \%$ immulab screen cells using CAT $\mathrm{NaCl}$. Criteria for optimal ratio selection were: (1) saliva plasma mixture must show negative reaction for complete inhibition, (2) saline plasma mixture needs to show strongest reaction to achieve least dilution effect.

\section{Spiking Anti Fy(a) Antibody in Patient Plasma}

To determine optimal anti-Fy(a) concentration, 5 mixtures of Immulab anti-Fy(a) reagent and plasma (from samples with no antibody) with different ratios (0:100, 4:100, 8:100, 16:100, and $25: 100)$ were set up. Each mixture was then tested against $0.8 \% \mathrm{im}$ mulab 11 cell panel using CAT LISS/Coomb IAT. The selection criteria was the lowest concentration showing reaction score 5-8.

\section{Detection of Spiked anti-Fy(a) after Saliva Inhibition}

Four mixtures were prepared, each containing 3 components: treated saliva or saline, Bombay plasma and anti-Fy(a) or saline using optimal saliva plasma reaction ratio and anti-Fy(a) spiking concentration. They were tested against Immulab $0.8 \%$ antibody identification cells with IAT method. Card 1 (saline/plasma/saline) served as a dilution control, where a positive reaction confirms anti-H reactivity; card 2 (treated saliva/plasma/saline) served as a negative control to ensure saliva treated Bombay plasma is free 
Table 1. Anti-H property

A Anti-H Ig subclass determination using DTT reagent (control: saline and plasma, DTT treatment: DTT and plasma)

\begin{tabular}{lllll}
\hline \multirow{2}{*}{ Antibody detection techniques } & \multicolumn{3}{l}{ Reaction score } \\
\cline { 3 - 5 } & & Cell 1 & Cell 2 & Cell 3 \\
\hline \multirow{2}{*}{ CAT (NaCl card) } & Control & 0 & 8 & 3 \\
& DTT treatment & 0 & 0 & 0 \\
\hline LISS/Coomb IAT & Control & 0 & 8 & 0 \\
& DTT treatment & 0 & 0 & 0 \\
\hline Tube IS & Control & 5 & 10 & 5 \\
& DTT treatment & 0 & 0 & 0 \\
\hline
\end{tabular}

B Thermal amplitude of anti-H

\begin{tabular}{llll}
\hline Temperature & Cell 1 & Cell 2 & Cell 3 \\
\hline $37^{\circ} \mathrm{C}$ & 5 & 8 & 5 \\
$30^{\circ} \mathrm{C}$ & 8 & 8 & 8 \\
$\mathrm{RT}$ & 8 & 10 & 8 \\
$4^{\circ} \mathrm{C}$ & 10 & 10 & 10 \\
\hline
\end{tabular}

of anti-H and alloantibodies; card 3 (saline/plasma/anti-Fy(a)) was used to show both anti-H and anti-Fy(a) reactivity; card 4 (treated saliva/plasma/anti-Fy(a)) was the test intended to demonstrate anti-Fy(a) reactivity thereby demonstrating the effectiveness of saliva inhibition in uncovering the spiked anti-Fy(a).

\section{Results}

Anti-H was identified as IgM as seen in Table $1 \mathrm{~A}$ where antibodies were only detected on plasma samples without DTT treatment. The failure of cell 1 to react could be due to the dilution effect and/or less $\mathrm{H}$ antigen on cell 1. The reaction score in Tube IS method was higher than those in CAT method which indicates Tube technique is more sensitive to detect anti-H.

Anti-H was proven to have a broad thermal amplitude reacting best at cold temperature as shown in Table $1 \mathrm{~B}$ where positive reactions were seen across all temperature and strongest at $4^{\circ} \mathrm{C}$.

From Table 2, 16:100 was selected as the optimum spiking ratio as it was the lowest concentration to demonstrate agglutination reaction strength 5-8.

The secretor test proved the volunteer is a secretor and presence of $\mathrm{H}$ antigen in saliva as a negative reaction was obtained in tube 4 (Table 3A).

$0.5: 1$ ratio was chosen as the optimal saliva/plasma ratio (Table 3B). With that ratio, saliva/plasma mixtures were negative while saline/plasma reactions obtained were the strongest. A single screen cell (screen cell 2) was used for the test due to scarcity of the sample. Cell 2 had
Table 2. Determination of optimum ratio of spiking anti-Fy(a) antibody in Bombay plasma

\begin{tabular}{llllllllllll}
\hline \multirow{2}{*}{$\begin{array}{l}\text { Anti-Fy(a) } \\
\text { antibody:plasma ratio }\end{array}$} & \multicolumn{10}{c}{$0.8 \%$ immulab 11 cell panel B } \\
\cline { 2 - 11 } & 1 & 2 & 3 & 4 & 5 & 6 & 7 & 8 & 9 & 10 & 11 \\
\hline $0: 100$ & 0 & 0 & 0 & 0 & 0 & 0 & 0 & 0 & 0 & 0 & 0 \\
$4: 100$ & 3 & 0 & 5 & 3 & 0 & 0 & 0 & 3 & 0 & 3 & 3 \\
$8: 100$ & 5 & 0 & 5 & 5 & 0 & 0 & 3 & 5 & 0 & 5 & 5 \\
$16: 100$ & 5 & 0 & 8 & 8 & 0 & 0 & 5 & 5 & 0 & 5 & 5 \\
$25: 100$ & 5 & 0 & 8 & 8 & 0 & 0 & 5 & 8 & 0 & 5 & 8
\end{tabular}

Phenocell B: Batch No.: 2653210 Exp: 21/12/2020.

strongest reaction compared with cells 1 and 3 in the previous Ig subclass and thermal amplitude test and therefore was considered to be the most sensitive indicator to monitor inhibition activity.

From Table 3C, card 4 shows the spiked anti-Fy(a) was successfully identified according to reaction profile of the identification panel. Card 3 showed anti-Fy(a) reactivity and weak anti-H interference. Card 1 showed weak anti$\mathrm{H}$ reactivity. Weak anti- $\mathrm{H}$ reactions can be due to dilution effect, low $\mathrm{H}$ antigen density on red cells and low anti- $\mathrm{H}$ reactivity at $37^{\circ} \mathrm{C}$. Inhibition was demonstrated to be successful by the negative reaction in card 2 .

\section{Discussion}

Anti-H in this study was detected as IgM which agrees with another case study by Jain et al., who also used DTT method [10]. Wide thermal amplitude found in this study correlated with two review articles by Vikrant and Chowdhury $[4,7]$. A new finding in our study was tube technique showed stronger reactions compared to CAT. Thus, we recommend using tube technique to detect anti$\mathrm{H}$.

In this study, it was the first time that treated saliva was used for alloantibody investigation and the result was promising as we detected spiked anti-Fy(a). Key elements for this method are: (1) $\mathrm{H}$ antigens need to be proven present in saliva by secretor test. (2) Saline controls are required for validation. (3) Optimal saliva/plasma ratio is not universal and needs to be determined each time. This is due to variation in the anti- $\mathrm{H}$ titer in Bombay individuals and soluble $\mathrm{H}$ antigen in the saliva as shown by variable reaction scores in Ig subclass and thermal amplitude tests.

There are some advantages to use this method compared to others. Although DTT method can eliminate IgM anti- $\mathrm{H}$, it also eliminates other IgM alloantibodies. Besides, DTT has no effect on IgG anti-H. In contrast, $\mathrm{H}$ 
Table 3. Saliva inhibition test

A Anti-H secretor status determination

\section{Reaction}

Anti-A, saline control, A1 cells 12

Anti-A, treated saliva, $A 1$ cells $\quad 12$

Anti-B, saline control, B cells 12

Anti-B, treated saliva, B cells

0

B Optimum treated saliva:Bombay plasma ratio for saliva inhibition test ( $0.8 \%$ screen cell 2 was used for the test)

\begin{tabular}{lll}
\hline $\begin{array}{l}\text { Saline/treated saliva: } \\
\text { Bombay plasma ratio }\end{array}$ & Saline + Bombay plasma & Treated saliva + Bombay plasma \\
\hline $2: 1$ & 3 & 0 \\
$1: 1$ & 3 & 0 \\
$0.5: 1$ & 5 & 0 \\
$0.25: 1$ & 8 & 3 \\
$0.125: 1$ & 8 & 3 \\
\hline
\end{tabular}

\section{Saliva inhibition test using treated saliva}

\begin{tabular}{|c|c|c|c|c|c|c|c|c|c|c|c|}
\hline \multirow{2}{*}{$\begin{array}{l}\text { Saliva inhibition } \\
\text { Saline/treated saliva + } \\
\text { Bombay plasma + saline/anti-Fy(a) } \\
\text { Ratio: 100:200:48 }\end{array}$} & \multicolumn{11}{|c|}{$0.8 \%$ immulab 11 cell panel B } \\
\hline & $\begin{array}{l}1 \\
\text { Fy(a+b-) }\end{array}$ & $\begin{array}{l}2 \\
\text { Fy }(a-b+)\end{array}$ & $\begin{array}{l}3 \\
F y(a+b-)\end{array}$ & $\begin{array}{l}4 \\
F y(a+b-)\end{array}$ & $\begin{array}{l}5 \\
F y(a-b+)\end{array}$ & 6 & $\begin{array}{l}7 \\
F y(a+b+)\end{array}$ & $\begin{array}{l}8 \\
F y(a+b-)\end{array}$ & $\begin{array}{l}9 \\
F y(a-b+)\end{array}$ & $\begin{array}{l}10 \\
F y(a+b+)\end{array}$ & $\begin{array}{l}11 \\
\text { Fy }(a+b-)\end{array}$ \\
\hline \multicolumn{12}{|l|}{ Card 1} \\
\hline $\begin{array}{l}\text { Saline }+ \text { plasma }+ \text { saline } \\
\text { Card } 2\end{array}$ & 3 & 3 & 3 & 0 & 3 & 3 & 3 & 0 & 3 & 3 & 0 \\
\hline $\begin{array}{l}\text { Treated saliva + plasma + saline } \\
\text { Card } 3\end{array}$ & 0 & 0 & 0 & 0 & 0 & 0 & 0 & 0 & 0 & 0 & 0 \\
\hline $\begin{array}{l}\text { Saline }+ \text { plasma }+ \text { anti-Fy(a) } \\
\text { Card } 4\end{array}$ & 5 & 3 & 5 & 5 & 3 & 0 & 5 & 5 & 0 & 5 & 5 \\
\hline Treated saliva + plasma + anti-Fy(a) & 3 & 0 & 5 & 5 & 0 & 0 & 3 & 3 & 0 & 3 & 5 \\
\hline
\end{tabular}

Ratio: 100:200:48 was derived from optimal treated saliva:Bombay plasma ratio in Table 3B and optimal spiking anti-Fy(a) concentration in Table 2

antigens in saliva specifically target all anti-H antibodies. Secondly, Red Cross Lifeblood in Australia uses blood of rare Bombay phenotype as a mini cell panel to detect underlying antibodies. However, it is often restricted by limited supply. In this case, saliva inhibition test can serve as a second option.

There are some limitations in our experiment: (1) antiFy(a) was artificially spiked, not immune derived alloantibodies. (2) Only anti-Fy(a) was studied due to limited samples available. (3) There were some weak or negative reactions in saline controls due to a dilutional effect, or low $\mathrm{H}$ antigen density on red cells leading to reduced anti- $\mathrm{H}$ reactivity at $37^{\circ} \mathrm{C}$.

A few improvements could be considered for future method design: (1) H content in the saliva could be concentrated and standardized to minimize dilution effect. (2) Other IgG and IgM antibodies could be further stud- ied. (3) Variation of anti-H in plasma, $\mathrm{H}$ antigen density on red cells and saliva need to be considered. (4) It may be worthy to include CAT $\mathrm{NaCl}$ in the detection of spiked anti-Fy(a) after saliva inhibition which may show stronger anti-H reactivity in dilution controls.

\section{Conclusion}

Although the Bombay blood group is rare, it should be considered possible for a Bombay patient to develop alloantibodies, particularly in pregnancy. In this article, we studied saliva inhibition in an attempt to detect anti-Fy(a) spiked into the Bombay plasma sample. The study showed tube is more sensitive than CAT technique in detecting anti-H. Anti-H in this sample was predominantly IgM, had broad thermal range, and reacted best at $4^{\circ} \mathrm{C}$. Saliva 
inhibition test was promising with some advantages and limitations. Further studies need to be done to improve this method.

\section{Acknowledgement}

Dr. Ellen Maxwell provided advisory and patient consent.

\section{Statement of Ethics}

The paper is exempt from ethical committee approval as it was low-risk research using leftover samples with permission from patient. Written informed consent was obtained from the patient for publication.

\section{Conflict of Interest Statement}

The authors have no conflicts of interest to declare.

\section{Funding Sources}

The authors have no funding sources to declare. All reagents and equipment access were provided by Melbourne Pathology and RMIT University.

\section{Author Contributions}

L.W. contributed to the method design, analysis, and writing of the article. D.E.J. contributed to the concept, design, and advisory. D.E.J., M.C, A.B., and D.C. provided resources and writing of the article. F.M. contributed to method design and resources.

\section{Data Availability Statement}

All data generated or analysed during this study are included in this article. Further enquiries can be directed to the corresponding author.

\section{References}

1 Bhende YM, Deshpande CK, Bhatia HM, Sanger R, Race RR, Morgan WT, et al. A "new" blood group character related to the ABO system. Lancet. 1952 May;1:903-4.

2 Ekanem E, Poozhikalayil S, Sinha A. The Bombay Blood Group: How Rare Is It? A Case Report and a Review of the Literature. JAMMR. 2020;32:24-9.

3 Koda Y, Soejima M, Johnson PH, Smart E, Kimura H. Missense mutation of FUT1 and deletion of FUT2 are responsible for Indian Bombay phenotype of $\mathrm{ABO}$ blood group system. Biochem Biophys Res Commun. 1997 Sep;238:21-5.

4 Vikrant N, Vivekanand K, Jyoti K, Sachin G. Bombay Blood Group: An Overview. Inventi Rapid: Pharmacy Practice. 2017;3:1-2.
5 Shahshahani HJ, Vahidfar MR, Khodaie SA. Transfusion reaction in a case with the rare Bombay blood group. Asian J Transfus Sci. 2013;7:86.

6 Shastry S, Lewis LE, Bhat SS. A rare case of haemolytic disease of newborn with Bombay phenotype mother. Asian J Transfus Sci. 2013;7:153-5.

7 Chowdhury F, Siddiqui M, Rahman K, Nasreen Z, Begum H, Begum H. A Rare and Clinically Important Blood Group - Bombay Blood Group. Bangla J Med. 2013;22(1):21-3.

8 Zaman S, Chaurasia R, Chatterjee K. Importance of including $\mathrm{O}$ cells in reverse grouping in detection of Bombay phenotype (Oh). J Clin Biomed Sci. 2014;4:333-4.

9 Priye S, Sathyanarayan J, Shivaprakash S, Reddy D. Perioperative management of patient with Bombay blood group undergoing mitral valve replacement. Indian J Anaesth. 2015;59:811-3.
10 Jain A, Kumawat V, Patil SS, Kumar P, Marwaha N, Sharma RR. Significance of serological monitoring in a Bombay Rh (D) negative phenotype pregnant woman: a case report. Transfus Apher Sci. 2012;47:251-2.

11 Byrne KM, Mercado CMC, Nnabue TN, Paige TD, Flegel WA. Inhibition of blood group antibodies by soluble substances. Immunohematology. 2019;35:19-22.

12 Pirofsky B, Rosner ER. DTT test: A new method to differentiate IgM and IgG erythrocyte antibodies. Vox Sang. 1974;27:480-8.

13 Byrne KM, Mercado CMC, Nnabue TN, Paige TD, Flegel WA. Inhibition of blood group antibodies by soluble substances. Immunohematology. 2019;35:19-22. 